\author{
Correspondence \\ Peter Kämpfer \\ peter.kaempfer@umwelt. \\ uni-giessen.de
}

\title{
Ochrobactrum rhizosphaerae sp. nov. and Ochrobactrum thiophenivorans sp. nov., isolated from the environment
}

\author{
Peter Kämpfer, ${ }^{1}$ Angela Sessitsch, ${ }^{2}$ Michael Schloter, ${ }^{3}$ Birgit Huber, ${ }^{4}$ \\ Hans-Jürgen Busse ${ }^{4}$ and Holger C. Scholz ${ }^{5}$
}

\author{
${ }^{1}$ Institut für Angewandte Mikrobiologie, Justus-Liebig-Universität Giessen, D-35392 Giessen, \\ Germany \\ ${ }^{2}$ Austrian Research Centers GmbH, Department of Bioresources, A-2444 Seibersdorf, Austria \\ ${ }^{3}$ Helmholtz Zentrum München, German Research Center for Environmental Health, Terrestrial \\ Ecogenetics, Ingolstaedter Landstrasse 1, D-85764 Neuherberg, Germany \\ ${ }^{4}$ Institut für Bakteriologie, Mykologie und Hygiene, Veterinärmedizinische Universität Wien, A-1210 \\ Wien, Austria \\ ${ }^{5}$ Bundeswehr Institute of Microbiology, D-80937 Munich, Germany
}

\begin{abstract}
Two Gram-negative, rod-shaped, non-spore-forming bacteria, PR $17^{\top}$ and DSM $7216^{\top}$, isolated from the potato rhizosphere and an industrial environment, respectively, were studied for their taxonomic allocation. By rrs (16S rRNA) gene sequencing, these strains were shown to belong to the Alphaproteobacteria, most closely related to Ochrobactrum pseudogrignonense (98.4 and 99.3\% similarity to the type strain, respectively). Chemotaxonomic data (major ubiquinone Q-10; major polyamines spermidine, sym-homospermidine and putrescine; major polar lipids phosphatidylethanolamine, phosphatidylmonomethylethanolamine, phosphatidylglycerol and phosphatidylcholine and the Ochrobactrum-specific unidentified aminolipid AL2; major fatty acids $\mathrm{C}_{18: 1} \omega 7 \mathrm{c}$ and $\mathrm{C}_{19: 0}$ cyclo $\omega 8 \mathrm{c}$ ) supported the genus affiliation. The results of DNA-DNA hybridization and physiological and biochemical tests allowed genotypic and phenotypic differentiation of the isolates from all hitherto-described Ochrobactrum species. Hence, both isolates represent novel species of the genus Ochrobactrum, for which the names Ochrobactrum

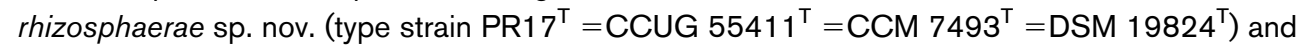
Ochrobactrum thiophenivorans sp. nov. (type strain DSM $7216^{\top}=$ CCUG $55412^{\top}=$ CCM $7492^{\top}$ ) are proposed.
\end{abstract}

The genus Ochrobactrum, introduced by Holmes et al. (1988), is a genus of which several novel species have recently been proposed. At the time of writing, the genus comprises the 11 species Ochrobactrum anthropi (the type species; Holmes et al., 1988), O. intermedium (Velasco et al., 1998), O. tritici and O. grignonense (Lebuhn et al., 2000), O. gallinifaecis (Kämpfer et al., 2003), O. lupini (Trujillo et al., 2005), O. oryzae (Tripathi et al., 2006), O. cytisi (Zurdo-Piñeiro et al., 2007), O. pseudintermedium (Teyssier et al., 2007), O. haematophilum and O. pseudogrignonense (Kämpfer et al., 2007b).

Abbreviations: pNA, p-nitroanilide; pNP, p-nitrophenyl.

The GenBank/EMBL/DDBJ accession numbers for the 16S rRNA gene sequences of strains $\mathrm{PR} 17^{\top}$ and $\mathrm{DSM} 7216^{\top}$ are respectively AM490632 and AM490617.
Strains PR $17^{\mathrm{T}}$ and DSM $7216^{\mathrm{T}}$ were both isolated from the environment. Strain $\mathrm{PR} 17^{\mathrm{T}}$ was isolated in Austria from the potato rhizosphere and strain DSM $7216^{\mathrm{T}}$ was isolated from wastewater in Germany. The latter strain was able to produce thiophene-2-carboxylate CoA esterase and utilizes thiophene 2-carboxylate as a sole source of carbon and sulfur (Kreimer, 1992). Both strains were presumptively identified as $O$. anthropi-like. They showed beige-coloured colonies on nutrient agar (Oxoid) at $37{ }^{\circ} \mathrm{C}$. Subcultivation was done on tryptone soy agar (TSA) at $28{ }^{\circ} \mathrm{C}$ for $48 \mathrm{~h}$.

Gram staining was performed as described by Gerhardt et al. (1994). Cell morphology was observed under a Zeiss light microscope at $\times 1000$, with cells grown for 3 days at $28^{\circ} \mathrm{C}$ on TSA. Partial 16S rRNA gene sequences (both $1387 \mathrm{bp}$ ) were studied as described by Kämpfer et al. (2003) and subsequent analysis was performed using the 
software package MEGA version 2.1 (Kumar et al., 2001) after multiple alignment of data by CLUSTAL_x (Thompson et al., 1997). Distances (distance options according to the Kimura-2 model) and clustering with the neighbourjoining and maximum-parsimony methods was performed by using bootstrap values based on 1000 replications. The $16 \mathrm{~S}$ rRNA gene sequences of these two strains were compared to each other and to entries in the nucleotide collection databases $(\mathrm{nr} / \mathrm{nt})$ using the BLASTN search tool available at http://www.ncbi.nlm.nih.gov/blast/Blast.cgi. The results of these calculations showed that the closest relative of strain $\mathrm{PR} 17^{\mathrm{T}}$ was strain DSM $7216^{\mathrm{T}}(98.7 \%$ similarity) and the type strain of $O$. pseudogrignonense, CCUG $30717^{\mathrm{T}}$ (98.4\% similarity). The closest relatives of strain DSM $7216^{\mathrm{T}}$ were O. pseudogrignonense CCUG $30717^{\mathrm{T}}$ (99.3\% similarity), strain PR $17^{\mathrm{T}}$ ( $98.7 \%$ similarity) and the type strain of O. haematophilum, CCUG $38531^{\mathrm{T}}$ ( $98.6 \%$ similarity). Lower sequence similarities were found with all other species of the genus Ochrobactrum. An rrsbased tree is shown in Fig. 1.

In recA-based phylogenetic analysis including the type strains of some Ochrobactrum and Brucella species, both strains again grouped close to O. grignonense but formed separate branches (Scholz et al., 2006; Fig. 2).

For polar lipid and quinone analyses, cells were grown on PYE medium $(0.3 \%$ peptone from casein, $0.3 \%$ yeast extract, $\mathrm{pH}$ 7.2). Extraction and analyses were carried out as described previously (Tindall, 1990a, b; Altenburger et al., 1996; Stolz et al., 2007). Polyamines were extracted and analysed as described by Busse \& Auling (1988) and Stolz et al. (2007). Detailed results of chemotaxonomic analyses are given in the species descriptions. Analysis of quinones revealed a spot that corresponded to ubiquinone-10 (Q10). The quinone system supports the affiliation of the two strains to the Alphaproteobacteria, where the majority of species have Q-10 as the major quinone (Lechner et al., 1995; Yokota et al., 1992); other Ochrobactrum species and unnamed Ochrobactrum strains have been reported to exhibit Q-10 as the major quinone (Lechner et al., 1995; Yokota et al., 1992; Kämpfer et al., 2003; Teyssier et al.,
2007; B. Huber and H.-J. Busse, unpublished results). The polyamine patterns, with the three predominant compounds putrescine, spermidine and sym-homospermidine, are in agreement with patterns reported previously for two species of this genus (Kämpfer et al., 2007b) and with the polyamine patterns of several other species of the genus (B. Huber and H.-J. Busse, unpublished results). Polar lipid profiles of $\mathrm{PR7}^{\mathrm{T}}$ and DSM $7216^{\mathrm{T}}$ exhibited only slight quantitative differences and strongly resembled the profiles of O. gallinifaecis (Kämpfer et al., 2003), O. haematophilum, O. pseudogrignonense (Kämpfer et al., 2007b) and other Ochrobactrum strains (B. Huber and H.-J. Busse, unpublished results). Furthermore, the characteristic unknown aminolipid AL2 was detected, which is absent from polar lipid extracts of representatives of the closely related genus Pseudochrobactrum (Kämpfer et al., 2006, 2007a).

Fatty acid methyl esters were prepared, separated and identified according to the instructions of the Microbial Identification System (MIDI Inc.) (Kämpfer \& Kroppenstedt, 1996). The fatty acid profiles of the three strains are shown in Table 1. No significant differences in the fatty acid profiles were found compared with other Ochrobactrum species.

Results of physiological and biochemical tests are given in the species descriptions and in Table 2. Tests were performed with methods described previously (Kämpfer et al., 1991). DNA-DNA hybridization experiments were performed with strains PR $17^{\mathrm{T}}$ and DSM $7216^{\mathrm{T}}$ and the type strains of the most closely related Ochrobactrum species, $O$. grignonense and $O$. pseudogrignonense, using the method described by Ziemke et al. (1998) except that, for nick translation, $2 \mu \mathrm{g}$ DNA was labelled during a $3 \mathrm{~h}$ incubation at $15{ }^{\circ} \mathrm{C}$. The results are shown in Table 3 .

Examinations based on almost entire rrs and recA gene sequences showed the affiliation of the two strains to the genus Ochrobactrum. In both trees (Figs 1 and 2), strains PR $17^{\mathrm{T}}$ and DSM $7216^{\mathrm{T}}$ grouped close to O. grignonense $\mathrm{OgA9a}^{\mathrm{T}}$ and O. pseudogrignonense CCUG $30717^{\mathrm{T}}$.

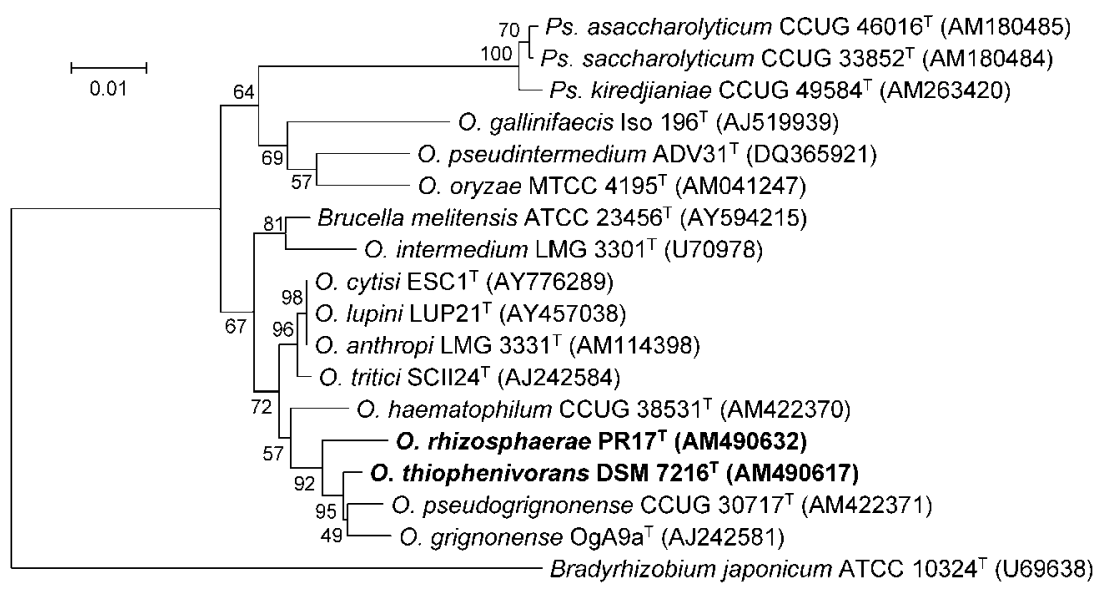

Fig. 1. Phylogenetic analysis based on $16 \mathrm{~S}$ rRNA gene (1387 bp) sequences available from the EMBL database (accession numbers in parentheses) constructed after multiple alignment of data by CLUSTAL_x (Thompson et al., 1997). Distances (distance options according to the Kimura-2 model) and clustering with the neighbour-joining method was performed by using the software package MEGA version 2.1 (Kumar et al., 2001). Bootstrap values based on 1000 replications are listed as percentages at branching points. Bar, 0.01 substitutions per nucleotide position. Ps., Pseudochrobactrum. 


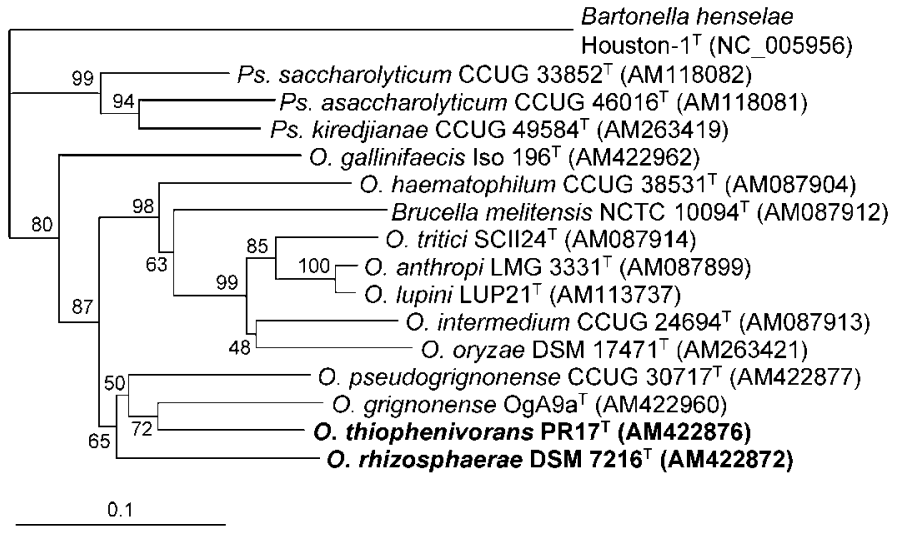

Fig. 2. Phylogenetic analysis based on $\operatorname{rec} A$ (879 bp) gene sequences. See legend to Fig. 1 for further details. Bar, 0.1 substitutions per nucleotide position.

However, DNA-DNA hybridization studies (Table 3) clearly demonstrated that the two strains represent separate species distinct from O. grignonense and O. pseudogrignonense. On the basis of these results, we describe two novel Ochrobactrum species.

\section{Description of Ochrobactrum rhizosphaerae sp. nov.}

Ochrobactrum rhizosphaerae [rhi.zo.sphae'rae. Gr. fem. n. rhiza root; L. fem. n. sphaera-ae (from Gr. fem. n. sphaira-as)

Table 1. Major fatty acids (\%) of the novel strains and type strains of closely related species of the genus Ochrobactrum

Strains: $1, \mathrm{PR}^{\mathrm{T}} \mathrm{7}^{\mathrm{T}}$ (O. rhizosphaerae sp. nov.); 2, DSM $7216^{\mathrm{T}}$ (O. thiophenivorans sp. nov.); 3, O. pseudogrignonense CCUG $30717^{\mathrm{T}}$; 4 , O. pseudogrignonense CCUG $43892^{\mathrm{T}} ; 5$, O. haematophilum CCUG $38531^{\mathrm{T}} ; 6$, O. grignonense DSM $13338^{\mathrm{T}} ; 7$, O. gallinifaecis Iso $196^{\mathrm{T}} ; 8$, O. intermedium LMG $3301^{\mathrm{T}}$; 9, O. anthropi CIP $14970^{\mathrm{T}}$; 10, O. tritici LMG $18957^{\mathrm{T}}$; 11, O. lupini LUP $21^{\mathrm{T}}$. All strains were grown on TSA at $28{ }^{\circ} \mathrm{C}$ for $48 \mathrm{~h}$ prior to fatty acid analysis. For unsaturated fatty acids, the position of the double bond is located by counting from the methyl $(\omega)$ end of the carbon chain; cis and trans isomers are indicated by the suffixes $c$ and $t$, respectively.

\begin{tabular}{|c|c|c|c|c|c|c|c|c|c|c|c|}
\hline Fatty acid & 1 & 2 & 3 & 4 & 5 & 6 & 7 & 8 & 9 & 10 & 11 \\
\hline \multicolumn{12}{|l|}{ Saturated fatty acids } \\
\hline $\mathrm{C}_{14: 0}$ & & & & & & & 0.7 & & & & \\
\hline $\mathrm{C}_{15: 0}$ & & & & 0.3 & & & & & & & \\
\hline $\mathrm{C}_{16: 0}$ & 8.3 & 7.3 & 9.7 & 9.2 & 10.8 & 2.9 & 8.9 & 3.7 & 6.6 & 3.7 & 5.8 \\
\hline $\mathrm{C}_{17: 0}$ & 2.8 & 1.4 & 1.6 & 2.1 & 2.5 & 1.7 & & 3.1 & 1.4 & 0.9 & 1.8 \\
\hline $\mathrm{C}_{18: 0}$ & 7.6 & 2.9 & 4.9 & 5.0 & 7.7 & 7.2 & 3.7 & 4.1 & 8.8 & 9.6 & 3.5 \\
\hline \multicolumn{12}{|l|}{ Unsaturated fatty acids } \\
\hline $\mathrm{C}_{13: 1}$ at $12-13$ & & & & & & 0.7 & & & 0.6 & & \\
\hline $\mathrm{C}_{17: 1} \omega 6 c$ & & & & & & 0.5 & & 1.1 & & & \\
\hline $\mathrm{C}_{18: 1} \omega 7 c$ & 61.5 & 40.9 & 19.2 & 24.2 & 32.7 & 31.6 & 28.8 & 25.8 & 45.6 & 77.9 & 57.3 \\
\hline 11-Methyl $\mathrm{C}_{18: 1} \omega 7 t$ & & 1.5 & 1.7 & 1.3 & & 1.0 & 1.6 & 1.5 & 1.0 & & 2.0 \\
\hline $\mathrm{C}_{20: 1} \omega 7 c$ & & & & 0.2 & & 0.8 & & & & & \\
\hline $\mathrm{C}_{20: 2} \omega 6,9 c$ & & 1.8 & 0.9 & 0.3 & 1.2 & 0.8 & 1.1 & 0.9 & 0.5 & & \\
\hline \multicolumn{12}{|l|}{ Hydroxy fatty acids } \\
\hline $\mathrm{C}_{18: 1} 2-\mathrm{OH}$ & 4.7 & 1.5 & 1.8 & 2.0 & & 0.5 & 1.5 & 1.8 & 0.6 & 1.4 & 1.8 \\
\hline $\mathrm{C}_{18: 0} 3-\mathrm{OH}$ & & & 0.5 & 0.6 & & 0.5 & & & & & \\
\hline Summed feature $3^{*}$ & 4.6 & 5.8 & 1.4 & 1.7 & 1.8 & 1.0 & 3.7 & 0.7 & 1.1 & 0.7 & 2.1 \\
\hline \multicolumn{12}{|l|}{ Cyclopropane acids } \\
\hline $\mathrm{C}_{17: 0}$ cyclo & & 2.1 & 1.0 & 1.3 & & & 2.9 & & 0.8 & & \\
\hline $\mathrm{C}_{19: 0}$ cyclo $\omega 8 c$ & 11.2 & 34.9 & 57.0 & 50.8 & 43.2 & 50.2 & 47.2 & 57.4 & 32.7 & 5.9 & 23.8 \\
\hline Unknown $13.957 \dagger$ & & & 0.3 & 0.2 & & 0.2 & & & & & \\
\hline Unknown $14.959 \dagger$ & & & & 0.3 & & 0.7 & & & 0.3 & & 2.0 \\
\hline
\end{tabular}

${ }^{\star}$ Summed features are groups of two or three fatty acids that cannot be separated by GLC with the MIDI system. Summed feature 3 contained $\mathrm{C}_{16: 1} \omega 7 c$ and/or $\mathrm{C}_{15: 0}$ iso $2-\mathrm{OH}$.

$\dagger$ Unknown fatty acids have no name listed in the peak library file of the MIDI system and therefore cannot be identified. 
Table 2. Physiological characteristics of the novel strains and type strains of closely related Ochrobactrum species

Strains: 1, PR $17^{\mathrm{T}}$ (O. rhizosphaerae sp. nov.); 2, DSM $7216^{\mathrm{T}}$ (O. thiophenivorans sp. nov.); 3, O. pseudogrignonense CCUG $30717^{\mathrm{T}}$ and CCUG 43892 ; 4, O. haematophilum CCUG $38531^{\mathrm{T}}$; 5, O. grignonense DSM $13338^{\mathrm{T}} ; 6$, O. anthropi CIP $14970^{\mathrm{T}} ; 7$, Ochrobactrum gallinifaecis Iso $196^{\mathrm{T}}$; 8, O. intermedium LMG $3301^{\mathrm{T}}$; 9, O. tritici LMG $18957^{\mathrm{T}}$; 10, O. lupini LUP $21^{\mathrm{T}}$; 11, O. oryzae DSM $17471^{\mathrm{T}}$ (data from Tripathi et al., 2006). +, Positive; -, negative; $(+)$, weakly positive; ND, no data available. All strains were positive for hydrolysis of L-alanine $p$-nitroanilide (pNA) and weak hydrolysis of bis-p-nitrophenyl (pNP) phosphate. All strains (except O. oryzae DSM $17471^{\mathrm{T}}$, for which not all tests were performed) were negative for hydrolysis of aesculin ${ }^{a \star}, \mathrm{pNP} \beta$-D-galactopyranoside ${ }^{a}$, pNP $\beta$-D-glucuronide, pNP $\alpha$-D-glucopyranoside, pNP $\beta$-D-glucopyranoside, pNP phosphorylcholine and 2-deoxythymidine- $5^{\prime}$-pNP phosphate. All strains were also positive for assimilation of L-arabinose ${ }^{a}, \mathrm{D}-$ galactose $^{a}, \mathrm{D}-\mathrm{glucose}$, D-mannose, D-ribose ${ }^{a}$, D-xylose, acetate, propionate ${ }^{a}$, fumarate ${ }^{a}$, glutarate, DL-lactate, L-malate ${ }^{a}$, oxoglutarate ${ }^{a}$, pyruvate ${ }^{a}$, L-alanine, L-proline, Lserine $^{a}$ and ornithine ${ }^{a}$. All strains were negative for assimilation of $p$-arbutin, salicin, putrescine, L-phenylalanine, L-tryptophan, 3-hydroxybenzoate, adipate $^{b}$, itaconate, mesaconate, phenylacetate ${ }^{a}$, melibiose ${ }^{a}$ and azelate.

\begin{tabular}{|c|c|c|c|c|c|c|c|c|c|c|c|}
\hline Test & 1 & 2 & 3 & 4 & 5 & 6 & 7 & 8 & 9 & 10 & 11 \\
\hline \multicolumn{12}{|l|}{ Hydrolysis of: } \\
\hline pNP phenylphosphonate & + & $(+)$ & $(+)$ & - & - & - & - & - & $(+)$ & - & $\mathrm{ND}$ \\
\hline L-Proline $\mathrm{pNA}^{b_{\star}}$ & + & + & + & + & + & + & + & $(+)$ & $(+)$ & + & ND \\
\hline \multicolumn{12}{|l|}{ Assimilation of: } \\
\hline D-Fructose, $m y o$-inositol ${ }^{a}$, D-sorbitol ${ }^{a}$, DL-3-hydroxybutyrate ${ }^{a}$ & + & + & + & + & + & + & - & + & + & + & + \\
\hline cis-Aconitate & + & - & + & + & + & + & - & + & + & - & + \\
\hline Citrate $^{a b}$ & + & - & + & + & + & + & - & + & + & + & - \\
\hline 4-Aminobutyrate, $\beta$-alanine ${ }^{a}$ & + & + & + & + & + & + & $(+)$ & + & + & + & ND \\
\hline Maltose $^{a b}$ & + & - & - & + & - & + & - & + & + & + & + \\
\hline D-Gluconate & - & + & + & + & + & + & + & + & + & $(+)$ & + \\
\hline$N$-Acetyl-D-glucosamine ${ }^{a}$ & $(+)$ & $(+)$ & - & + & - & + & - & + & + & + & + \\
\hline Cellobiose $^{a c}$ & + & - & - & - & - & + & - & + & - & - & ND \\
\hline$N$-Acetyl-D-galactosamine & + & + & + & - & + & $(+)$ & - & + & + & + & ND \\
\hline Suberate $^{a}$ & - & - & - & - & - & - & - & - & + & - & ND \\
\hline L-Aspartate ${ }^{a}$ & + & + & + & + & + & + & + & + & - & + & + \\
\hline 4-Hydroxybenzoate & - & - & - & + & - & $(+)$ & - & $(+)$ & + & + & ND \\
\hline L-Histidine $e^{a}$ & + & - & + & + & + & + & + & + & $(+)$ & + & + \\
\hline L-Leucine ${ }^{a}$ & + & - & + & + & + & + & - & + & $(+)$ & + & + \\
\hline
\end{tabular}

${ }^{\star}$ Test (based on a different method) was also performed as follows and gave congruent results: $a$, Holmes et al. (1988) with O. anthropi; $b$, Velasco et al. (1998) with O. intermedium; $c$, Lebuhn et al. (2000) with type strains of all four previously described species.

$\dagger$ Strain CCUG $30717^{\mathrm{T}}$ showed only weakly positive results.

ball, any globe, sphere; N.L. gen. fem. n. rhizosphaerae of the rhizosphere].

Cells from the early exponential growth phase are stongly motile, but may become less motile or non-motile when approaching the stationary growth phase. Cells are non-spore-forming rods (approx. $2 \mu \mathrm{m}$ long). Gramnegative and oxidase-positive, showing an oxidative metabolism. Good growth occurs on R2A agar, TSA, nutrient agar, PYE agar and MacConkey agar at $25-30{ }^{\circ} \mathrm{C}$. Colonies are beige, translucent and shiny. Colonies with entire edges are formed within $24 \mathrm{~h}$, with a diameter of

Table 3. DNA-DNA reassociation (\%) between the novel strains and closely related Ochrobactrum type strains

\begin{tabular}{|lcccc|}
\hline Strain & PR17 $^{\mathbf{T}}$ & DSM $7216^{\mathbf{T}}$ & O. $^{\text {grignonense }}$ DSM 13338 & O. $^{\mathrm{T}}$ pseudogrignonense CCUG 30717 $^{\mathrm{T}}$ \\
\hline PR $17^{\mathrm{T}}$ & 100 & - & 40.0 & 27.3 \\
DSM $7216^{\mathrm{T}}$ & 32.1 & 100 & 33.3 & 24.2 \\
\hline
\end{tabular}


approximately $2 \mathrm{~mm}$. The quinone system consists of Q-10 $(99 \%)$ and Q-9 (1\%). The polyamine pattern consists of the major compounds spermidine $[28 \mu \mathrm{mol}$ (g dry weight $\left.)^{-1}\right]$, putrescine $\left[41 \mu \mathrm{mol}(\mathrm{g} \text { dry weight })^{-1}\right]$ and sym-homospermidine $\left[10 \mu \mathrm{mol}(\mathrm{g} \text { dry weight })^{-1}\right]$ and minor amounts of 1,3-diaminopropane $[1 \mu \mathrm{mol}$ (g dry weight $\left.)^{-1}\right]$ and spermine $\left[<1 \mu \mathrm{mol}(\mathrm{g} \text { dry weight })^{-1}\right]$. Predominant polar lipids are phosphatidylethanolamine, phosphatidylmonomethylethanolamine, phosphatidylglycerol, phosphatidylcholine and diphosphatidylglycerol. Moderate to minor amounts of phosphatidyldimethylethanolamine and two unidentified aminolipids AL1 and the Ochrobactrum-specific AL2 and traces of several unknown lipids are also present. The fatty acid profile is composed mainly of $\mathrm{C}_{18: 1} \omega 7 c(61.5 \%)$ and $\mathrm{C}_{19: 0}$ cyclo $\omega 8 c(11.2 \%)$. Carbon source utilization and hydrolysis of chromogenic substrates (including differentiating characters for all Ochrobactrum species) are indicated in Table 1.

The type strain PR $17^{\mathrm{T}}\left(=\right.$ CCUG $55411^{\mathrm{T}}=\mathrm{CCM} 7493^{\mathrm{T}}$ $=$ DSM $19824^{\mathrm{T}}$ ) was isolated from the potato rhizosphere in Austria.

\section{Description of Ochrobactrum thiophenivorans sp. nov.}

Ochrobactrum thiophenivorans (thi'o.phe.ni.vo'rans. N.L. n. thiophenum thiophene; L. part. adj. vorans devouring; N.L. part. adj. thiophenivorans thiophene-devouring, referring to the ability to utilize thiophene 2-carboxylate as a sole source of carbon and sulfur).

Cells are non-motile, non-spore-forming rods (approx. $2 \mu \mathrm{m}$ long). Gram-negative and oxidase-positive, showing an oxidative metabolism. Good growth occurs on R2A agar, TSA, PYE agar, nutrient agar and MacConkey agar at 25$30{ }^{\circ} \mathrm{C}$. Forms beige, translucent and shiny colonies with entire edges within $24 \mathrm{~h}$, with a diameter of approximately $2 \mathrm{~mm}$. The quinone system consists of Q-10 (99\%) and Q-9 $(1 \%)$. The polyamine pattern consists of the major compounds spermidine $\left[28 \mu \mathrm{mol}(\mathrm{g} \text { dry weight })^{-1}\right]$, putrescine $\left[19 \mu \mathrm{mol}(\mathrm{g} \text { dry weight })^{-1}\right]$ and sym-homospermidine $\left[9 \mu \mathrm{mol}(\mathrm{g} \text { dry weight })^{-1}\right]$ and minor amounts of $1,3-$ diaminopropane $\left[4 \mu \mathrm{mol}(\mathrm{g} \text { dry weight })^{-1}\right]$ and spermine $\left.[2 \mu \mathrm{mol} \text { (g dry weight })^{-1}\right]$. Predominant polar lipids are phosphatidylethanolamine, phosphatidylmonomethylethanolamine, phosphatidylglycerol, phosphatidylcholine, diphosphatidylglycerol and the unknown Ochrobactrumspecific aminolipid AL2. Moderate amounts of phosphatidyldimethylethanolamine and another unidentified aminolipid AL1 and small to trace amounts of several unknown lipids are also present. The fatty acid profile is composed mainly of $\mathrm{C}_{18: 1} \omega 7 c(19.2 \%)$ and $\mathrm{C}_{19: 0}$ cyclo $\omega 8 c(57.0 \%)$. Carbon source utilization and hydrolysis of chromogenic substrates (including differentiating characters for all Ochrobactrum species) are indicated in Table 2.

The type strain DSM $7216^{\mathrm{T}}\left(=\right.$ CCUG $55412^{\mathrm{T}}=\mathrm{CCM}$ $7492^{\mathrm{T}}$ ) was isolated from wastewater in Germany.

\section{Acknowledgements}

We thank J. P. Euzéby for his help with the etymology of the specific epithets and Birgit Mitter for helpful discussions. The work of B. H. and H.-J.B. was supported by a Contract Research Project for the Bundeswehr Medical Service.

\section{References}

Altenburger, P., Kämpfer, P., Makristathis, A., Lubitz, W. \& Busse, H.-J. (1996). Classification of bacteria isolated from a medieval wall painting. J Biotechnol 47, 39-52.

Busse, H.-J. \& Auling, G. (1988). Polyamine pattern as a chemotaxonomic marker within the Proteobacteria. Syst Appl Microbiol 11, 1-8.

Gerhardt, P., Murray, R. G. E., Wood, W. A. \& Krieg, N. R. (editors) (1994). Methods for General and Molecular Bacteriology. Washington, DC: American Society for Microbiology.

Holmes, B., Popoff, M., Kiredjian, M. \& Kersters, K. (1988). Ochrobactrum anthropi gen. nov., sp. nov. from human clinical specimens and previously known as group Vd. Int J Syst Bacteriol 38, 406-416.

Kämpfer, P. \& Kroppenstedt, R. M. (1996). Numerical analysis of fatty acid patterns of coryneform bacteria and related taxa. Can J Microbiol 42, 989-1005.

Kämpfer, P., Steiof, M. \& Dott, W. (1991). Microbiological characterisation of a fuel-oil contaminated site including numerical identification of heterotrophic water and soil bacteria. Microb Ecol 21, 227-251.

Kämpfer, P., Buczolits, S., Albrecht, A., Busse, H.-J. \& Stackebrandt, E. (2003). Towards a standardized format for the description of a novel species (of an established genus): Ochrobactrum gallinifaecis sp. nov. Int J Syst Evol Microbiol 53, 893-896.

Kämpfer, P., Rosselló-Mora, R., Scholz, H., Welinder-Olsen, C. \& Busse, H.-J. (2006). Description of Pseudochrobactrum gen. nov., with the two species Pseudochrobactrum asaccharolyticum sp. nov. and Pseudochrobactrum saccharolyticum sp. nov. Int J Syst Evol Microbiol 56, 1823-1829.

Kämpfer, P., Scholz, H., Huber, B., Thummes, K., Busse, H.-J., Maas, E. W. \& Falsen, E. (2007a). Description of Pseudochrobactrum kiredjianiae sp. nov. Int J Syst Evol Microbiol 57, 755-760.

Kämpfer, P., Scholz, H. C., Falsen, E. \& Busse, H.-J. (2007b). Ochrobactrum haematophilum sp. nov. and Ochrobactrum pseudogrignonense sp. nov., isolated from human clinical specimens. Int $J$ Syst Evol Microbiol 57, 2513-2518.

Kreimer, S. (1992). Untersuchungen zum Stoffwechsel von Thiophen-2carboxylat in Agrobacterium tumefaciens und Ochrobactrum anthropi und Reindarstellung einer CoA-Esterase. Doctoral thesis, University Göttingen, Germany (in German).

Kumar, S., Tamura, K., Jakobsen, I.-B. \& Nei, M. (2001). MEGA2: molecular evolutionary genetics analysis software. Bioinformatics 17, 1244-1245.

Lebuhn, M., Achouak, W., Schloter, M., Berge, O., Meier, H., Barakat, M., Hartmann, A. \& Heulin, T. (2000). Taxonomic characterization of Ochrobactrum sp. isolates from soil samples and wheat roots, and description of Ochrobactrum tritici sp. nov. and Ochrobactrum grignonense sp. nov. Int J Syst Evol Microbiol 50, 2207-2223.

Lechner, U., Baumbach, R., Becker, D., Kitunen, V., Auling, G. \& Salkinoja-Salonen, M. (1995). Degradation of 4-chloro-2-methylphenol by an activated sludge isolate and its taxonomic description. Biodegradation 6, 83-92. 
Scholz, H. C., Tomaso, H., Al Dahouk, S., Witte, A., Schloter, M., Kämpfer, P., Falsen, E. \& Neubauer, H. (2006). Genotyping of Ochrobactrum anthropi by recA-based comparative sequence, PCRRFLP, and 16S rRNA gene analysis. FEMS Microbiol Lett 257, 716.

Stolz, A., Busse, H.-J. \& Kämpfer, P. (2007). Pseudomonas knackmussii sp. nov. Int J Syst Evol Microbiol 57, 572-576.

Teyssier, C., Marchandin, H., Jean-Pierre, H., Masnou, A., Dusart, G. \& Jumas-Bilak, E. (2007). Ochrobactrum pseudintermedium sp. nov., a novel member of the family Brucellaceae, isolated from man. Int J Syst Evol Microbiol 57, 1007-1013.

Thompson, J. D., Gibson, T. J., Plewniak, F., Jeanmougin, F. \& Higgins, D. G. (1997). The CLUSTAL_X windows interface: flexible strategies for multiple sequence alignment aided by quality analysis tools. Nucleic Acids Res 25, 4876-4882.

Tindall, B. J. (1990a). A comparative study of the lipid composition of Halobacterium saccharovorum from various sources. Syst Appl Microbiol 13, 128-130.

Tindall, B. J. (1990b). Lipid composition of Halobacterium lacusprofundi. FEMS Microbiol Lett 66, 199-202.

Tripathi, A. K., Verma, S. C., Chowdhury, S. P., Lebuhn, M., Gattinger, A. \& Schloter, M. (2006). Ochrobactrum oryzae sp. nov., an endophytic bacterial species isolated from deep-water rice in India. Int J Syst Evol Microbiol 56, 1677-1680.

Trujillo, M. E., Willems, A., Abril, A., Planchuelo, A. M., Rivas, R., Ludeña, D., Mateos, P. F., Martínez-Molina, E. \& Velázquez, E. (2005). Nodulation of Lupinus by strains of the new species Ochrobactrum lupini sp. nov. Appl Environ Microbiol 71, 1318-1327.

Velasco, J., Romero, C., López-Goñi, I., Leiva, J., Díaz, R. \& Moriyón, I. (1998). Evaluation of the relatedness of Brucella spp. and Ochrobactrum anthropi and description of Ochrobactrum intermedium sp. nov., a new species with a closer relationship to Brucella spp. Int $J$ Syst Bacteriol 48, 759-768.

Yokota, A., Akagawa-Matsushita, M., Hiraishi, A., Katayama, Y., Urakami, T. \& Yamasato, K. (1992). Distribution of quinone systems in microorganisms: gram-negative Eubacteria. Bull Jpn Fed Cult Coll 8, 136-171.

Ziemke, F., Höfle, M. G., Lalucat, J. \& Rosselló-Mora, R. (1998). Reclassification of Shewanella putrefaciens Owen's genomic group II as Shewanella baltica sp. nov. Int J Syst Bacteriol 48, 179-186.

Zurdo-Piñeiro, J. L., Rivas, R., Trujillo, M.E., Vizcaíno, N., Carrasco, J. A., Chamber, M., Palomares, A., Mateos, P. F., Martínez-Molina, E. \& Velázquez, E. (2007). Ochrobactrum cytisi sp. nov. isolated from nodules of Cytisus scoparius in Spain. Int J Syst Evol Microbiol 57, 784-788. 